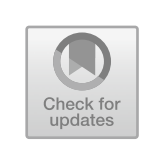

\title{
Syllabic Gasps: M. NourbeSe Philip and Charles Olson's Poetic Conspiration
}

\section{Stefanie Heine}

In response to Nathaniel Mackey's Inaugural Robert Creeley Lecture in Poetry and Poetics 2016, 'Breath and Precarity', M. NourbeSe Philip reframed her book Zong! in respiratory terms. The starting point of her essay 'The Ga(s)p' is Mackey's exploration of a 'poetics of breath'. Mackey traces this poetics back to the 'pneumatic turn' in the 1950s and 1960s, when breath-measure became a key term in attempts to emancipate literary composition from inherited traditions and writers like Charles Olson, Allen Ginsberg, and Amiri Baraka formulated their principles for a new American literature. The breath that 'was in the air' ${ }^{2}$ then found its most prominent and palpably 'tactile' (8) expression in black music, especially jazz. This black context of respirational poetics is inextricably linked with Mackey's main argument: 'an artistic turn to breath' is symptomatic of 'individual and collective anxiety and insecurity' (6). As he argues, artists in post-war America found themselves in a 'post-traumatic' (6) period in which 'mortal susceptibility' and 'human exposure' (7) were

\footnotetext{
S. Heine $(\bowtie)$

Department of Arts and Cultural Studies, Comparative Literature, University of Copenhagen, Copenhagen, Denmark

(C) The Author(s) 2021 463

D. Fuller et al. (eds.), The Life of Breath in Literature, Culture and Medicine, Palgrave Studies in Literature, Science and Medicine, https://doi.org/10.1007/978-3-030-74443-4_22
} 
predominant on a broader socio-demographic scale. This precarious state is compared to the ongoing black experience of being subjected to a 'long state of siege', 'a long history crystallized most recently by Eric Garner's last words in a police officer's chokehold, "I can't breathe" (13). Mackey suggests an explanation for the turn to breath in atmospheres of heightened anxiety: it implies returning 'to the basics' in moments when everything becomes uncertain. Such a turn to the elementary physiological process that keeps us alive also means going back 'to the primal or primitive doubts' ( 6 , my emphasis). Breath, especially black breath, is as such 'subject' to 'precarity' (16) and it matters 'especially if at risk' (17).

Philip, whose literary and essayistic work continually engages with racism, violence against people of colour, and colonial and postcolonial oppression, connects with Mackey's idea of precarity as it affects African Americans' (32). In her essay, she takes literally his claim that such precarity effects a 'return to the basics' and the 'primal'. The essay opens with an intrauterine scene:

WE ALL BEGIN life in water

We all begin life because someone once breathed for us

Until we breathe for ourselves

Someone breathes for us

Everyone has had someone-a woman-breathe for them

Until that first $\mathrm{ga}(\mathrm{s}) \mathrm{p}$

For air ('The Ga(s)p', 31)

Philip does not only give a feminist twist to Mackey's exclusively male history of a poetic 'pneumatism'. ${ }^{3}$ The scene she sketches also reacts to a number of prominent discussions by white men of the intrauterine state and the first breath. Otto Rank claimed 'that all anxiety goes back originally to the anxiety at birth (dyspnoea)'. ${ }^{4}$ This feeling of suffocation supposedly coincides with the 'primal trauma' 5 an infant suffers when it is forced to leave an idealized condition of 'intrauterine primal pleasure'. ${ }^{6}$ Another theoretical interpretation follows a passing observation taken by Merleau-Ponty from Henri Wallon: the infant's 'body is already a respiratory body'. In relation to this remark, David Michael KleinbergLevin states that '[b]reathing is our most primordial ecstatic openness', teaching the infant 'interdependency', 'giving and receiving'. ${ }^{8}$ Along the same lines, but drawing on Peter Sloterdijk's discussion of the 'respiratory phase' as the cultural theorist Thomas Macho reinterprets it, Leo 
Bersani argues that 'inhaling and exhaling' are 'our earliest transactions with exteriority'. ' Bersani's 'analyses of "receptive bodies"', ranging from explorations of queer to non-human receptivity, include a depiction of 'intrauterine origin' 10 that in many respects resonates with Philip's:

With its first, exuberantly welcomed scream, the human infant announces its respiratory interdependence. Within the womb, it could rely on the mother breathing for it. Having accomplished the at once biologically and symbolically necessary severance from the mother's breathing rhythm, she is on her own, dependent on her own lungs to sustain the precarious individual life into which she has just fallen. Breathing is the tiny human's first experience of her body's inescapable receptivity: absorption and expulsion. ${ }^{11}$

The conception of a fundamental 'respiratory interdependence' and exposure in a particularly feminine framework, which Bersani highlights through his focus on the mother's act of 'breathing for' the infant as well as the child's gendering, is precisely what Philip develops further.

Inspired by Hannah Arendt's thoughts on natality, Philip argues concerning the 'idea of the mother breathing for the foetus' that this 'process of shared breath [...] and dependency becomes useful as a model of community and connectedness in a more female-centred, embodied, symbolic universe' ('The Ga(s)p', 36). The 'imperative to lodge the poetics of breath as identified by Mackey in the Black female imaginary' (36) immediately leads her to the question 'How do we begin to think about shared breath, circular breath, or circle breath in the context of force-historical (enslavement) and contemporary' (36)? Upon finding that the $O E D$ gives one definition of 'gasp' as 'the last attempt to breathe before death' (34), Philip outlines a respiratory short-circuit:

The first $g a(s) p$ of the newborn who has, until then, been breathed for, signals a beginning; it is the same act-that of forcefully attempting to draw air into the lungs that will mark the final moment of a life- "I can't breathe...." The last words uttered by Eric Garner as he lay dying on a New York sidewalk. (34)

In the 'Black female imaginary', a history of violence and suppression also pervades the intrauterine setting that has often been stylized as a paradisial origin. From her general observation that '[b]reathing for the other' is an 
'expression of radical hospitality' (34), '[r] adical because [...] physiologically the child is also a stranger' (34-35) onwards, Philip's language is infiltrated by a vocabulary of colonial force: 'housing the stranger, which includes breathing for the occupant' is an 'act of acceptance of alterity' (35, my emphasis). She then turns to a scenario in which the stranger is violently imposed on the woman's body: the 'forced breeding of enslaved African women' and 'the forced impregnation by white and European masters' (35).

While the gender-political and racial concerns of Philip's delineation of shared breath are apparent, it is so far still unclear how it relates to a poetics of breath. The poetic implications of Philip's reflections on respiration become most specific when she turns to biochemical matters. As she points out, the mother's 'radical hospitality' of breathing for the unborn child is facilitated by the body's molecular processes: 'Ordinarily, the mother should generate activated T-cells, which would then attack the foetus's foreign antigens'. Instead, the 'mother's body turns off the functions of her T-cells, which would normally result in the rejection of the foetus' (35). Philip's excursion into the field of biology turns out to be the crucial link to the poetics of breathing and fragmentation she exemplifies with her book Zong!. Biochemical vocabulary is what the primal scene, the model of community, and the comments on Zong! share in 'The Ga(s)p'. In this context, cell-memory is the central focus:

Do our cells carry this epigenetic memory of a form of sharing and exchange, a modelling of a "we" that we can take into our varied practices? Do they, our cells, remember what it was like to have someone breathe for us? And how, if at all, does the epigenetic cellular memory of the forced breathing of Black women affect this most generative and generous of acts? Are we marked by this - by having someone breathe for us? A memory that is a blueprint for community and interdependency. Despite the forced couplings. (38)

The potential 'cellular memory' that might be shared is punctured by loss and deprivation: someone once breathed for us, gave her breath away; she might have been forced to do so, after her freedom and body were taken; at the outset, our breath was not our own, and probably it never is, never will be. 
What Philip outlines in 'The Ga(s)p' goes hand in hand with JeanLuc Nancy's notion of 'inoperative community'. For Nancy, being-incommon is based on a lack and 'the common is the sharing of finitude'. 12 Thereby, he understands 'sharing' as the 'condition of being-exposed', drawing on the French implications of 'partage', ${ }^{13}$ which also means dividing or splitting into parts. Philip imagines a very visceral partage: a communal sharing of particles, cell-carried memory. Her suggested 'blueprint for community', the common memory of 'what it was to have someone breathe for us', implies recalling an 'act of acceptance of alterity' ('The Ga(s)p', 35): our bodies' smallest parts remember an intimate sharing of breath with what is most disparate-the Other, the occupant. In Nancy's words: 'partage', the basis of community, always entails that 'I experience the other's alterity, or I experience [...] the alterity [... "in me". ${ }^{14}$ Nancy argues that "community cannot be presupposed. It is only exposed'. 15 Philip calls the 'memory that is a blueprint for community' into question: 'Do they, our cells, remember what it was like to have someone breathe for us?'. Consequently, what Philip's imagined community shares, what it rests upon, is neither given nor granted; it is precarious, left open, exposed. This is the uncertain foundation on which Philip bases her 'poetics of breath' or 'poetics of the fragment', a 'distinction without a difference' (39), as she claims. Zong!, which 'illuminates' this poetics, consists of 'fragments driven pneumatically' (39) and amounts to a partage of smallest particles, cells: 'When I perform Zong!, I allow the words and word clusters to breathe for the I n' I-for the we in us that we carry within the memory of our cells. When I invite the audience to read with me, we collectively engage in breathing for the Other-for those who couldn't breathe' (39).

In the context of Zong!, 'breathing for the Other' and sharing mortality points to a very specific scenario of racial violence. '[T]hose who couldn't breathe' refers to 150 African Americans who were deliberately drowned on board the slave ship Zong in 1781, a massacre committed for financial reasons during a voyage on the Middle Passage that due to navigational errors took much longer than expected. As Philip summarizes, when water supplies were getting short, the ship's captain 'was of the belief that if the African slaves on board die a natural death, the owners of the ship will have to bear the cost, but if they "were thrown alive into the sea, it would be the loss of the underwriters". 16 The matter turned into a legal dispute, resulting in a trial brought by the ship's owners and an appeal by the insurers, heard in the King's Bench and recorded in the report 
Gregson v. Gilbert. The fragmented language of Zong! consists exclusively of linguistic material from the report of the appeal. Philip pulls the legal text apart, rearranges sentences and words, 'carv[es] words out of other words' (Zong!, 198) and tears them apart into isolated letters and syllables. In an interview, she describes this process of un-writing in a way that directly ties in with her speculation about the 'memory of our cells': 'It is as if in fragmenting the words, the stories locked in DNA [sic] of those words are released'. 17 The 'DNA' to which Philip alludes is unlocked most effectively when the text is ripped to the smallest pieces- the word's cells: syllables, letters.

As Philip stresses, this act of 'explod[ing] the words' (Zong!, 203) makes them 'break into sound' (205) and the legal text is transformed 'into a cacophony of voices-wails, cries, moans, and shouts' (203): 'o', 'oo', 'oh', 'w', 'waa', 'a', 'ah', etc. (3). In the 'Notanda' accompanying Zong!, we find, in precisely this context, a sentence that echoes her question 'Do they, our cells, remember what it was like to have someone breathe for us?': 'Do they, the sounds, the cries, the shouts of those thrown overboard from the Zong repeat themselves over and over until they rise from the ocean floor to resurface in Zong? It is a question that haunts me' (203-04). Juxtaposed thus, these questions display a transition from commemoration to haunting that lies at the heart of Zong! and Philip's poetics of breath: 'Zong! is hauntological' (201). The uncertainty of a respirational cell-memory mirrors the uncertainty around the textually recovered moans and groans of the drowning slaves. At times, Philip seems to be confident that the violently silenced voices can be recovered in her poetry:

In Zong!, the African, transformed into a thing by the law, is retransformed, miraculously, back into human.

Through oath and through moan, through mutter, chant and babble, through babble and curse, through chortle and ululation. (196)

Against this wish for a magical re-humanisation of the victims, the incorporation of their dying breaths to the text turns into a 'haunting' question-a question that also unsettles the more moderate hope that they can be remembered at all. From the outset, Philip stresses that Zong! is composed around an irrecoverable loss. The Africans who died on the Zong were subject to a double silencing: their voices were suffocated in the sea and by-passed by historical documentation-the surviving report 
anonymizes and dehumanizes them as cargo. Addressing the erasure of the Africans in the textual basis of Zong!, Christina Sharpe succinctly concludes: 'Breathlessness and the archive: the archives of breathlessness'. ${ }^{18}$ The breath taken from the slaves, their lost struggle for air in the water, is 'lessened', left unarchived, in the suffocating historical document Gregson v. Gilbert. As a consequence of this ultimate silencing, the murdered slaves cannot be re-called, just as their bones cannot be recovered 'exaqua' (Zong!, 201). ${ }^{19}$

Philip's poetic project to a large extent consists in exposing the impossibility of remembering the dead. The imagined transference of the dying Africans' gasps into word-cells is ruptured by the gap that was torn open when they were silenced. Such a ga(s)p in memory is poetically staged in Philip's earlier collection of poetry, She Tries Her Tongue, Her Silence Softly Breaks, when she tears the word 're-member' apart and thereby inscribes a blank space. In the poem 'Universal Grammar', the method of linguistic dissecting, or 'parsing', is performatively displayed with words that later become crucial for the poetics of Zong! as delineated in the 'Notanda' and later in 'The Ga(s)p':

the smallest cell

$$
\begin{aligned}
& \text { remembers } \\
& \text { a sound }
\end{aligned}
$$

On the page before, these words, here arranged in verses, appear as follows:

Parsing - the exercise of telling the part of speech of each sentence (Latin, pars, a part)

The-distinguishing adjective, limiting the noun, cell. smallest-adjective of quantity [...], cell (unsuccessfully) cell—common noun $[\ldots]$, remembers. (Long-term memory improves cell growth in nerve cells.)

remembers-regular verb $[\ldots]$ cell which remembers and so re-members. $\mathrm{O}-$ sound of exclamation [...] (She Tries Her Tongue, 36)

The sentence 'the smallest cell remembers a sound', or 'the smallest cell remembers O' (a sound that will conspicuously pervade Zong! - i.e. one of the ga(s)ping word-cells that might re-member but fails to bring back the voices of the slaves) is 'parsed': each line following the sentence's vertically arranged words mimics a dictionary entry. 
On the following pages, two further explications gesture towards the ambivalence inherent in Philip's respirational poetics of the fragment: 'fragments-common noun [...] Re-membered fragments become whole' (38). 'Parsing - the exercise of dis-membering language into fragmentary cells that forget to re-member' (40). The first 'definition' plays with a phantasy of recovery: when scattered parts are reassembled and memory is recuperated, dismembered bodies too might become whole again. The second one alludes to the flipside of fragmentation: dissecting language - be it analytically ('parsing') or poetically (Philip's own method, employed in this poem as well as in Zong!)-implies that it falls to pieces which cannot be put together again seamlessly; cells might not re-member, in both senses. Or, in other words, the concept of 're-membering' as commemoration effected by scattering fragments and word-cells contains a gap, a potential loss:

$$
\begin{aligned}
& \text { when the smallest cell } \\
& \text { remembers } \\
& \text { lose a language (4l) }
\end{aligned}
$$

The proximity of 'lose a language' and 'loose a language' is not only acoustic. The fragmented poetry of Zong! displays this on two levels: it both exhibits a language that has been lost and cannot be remembered, and stages 'intelligible words' turning into prelinguistic 'sound' (33), words losing what qualifies them as constituents of a system of meaningful signs.

The tension between 'intelligible words' and 'sound' brings us back to breath and to the intrauterine scene sketched by Philip in 'The Ga(s)p'. The 'Discourse on the Logic of Language', which immediately precedes 'Universal Grammar' in She Tries Her Tongue, contains the following mock multiple-choice exercise:

Air is forced out of the lungs up the throat to the larynx where it causes the vocal chords to vibrate and create sound. The metamorphosis from sound to intelligible word requires
a. the lip, tongue and jaw working together.
b. a mother tongue.
c. the overseer's whip.
d. all of the above or none. (33) 
Philip's account of respiration and language production, already shadowed by a sense of violence through the formulation '[a]ir is forced out of the lungs', is embedded in the history of slavery ('the overseer's whip'). How this relates to (a) and especially (b) is elucidated in the preceding parts of the text, which poetically negotiate the ambivalent relation from a black perspective to English as a 'mother tongue' (30). Even though it might be their first one, the 'language' inherited from the colonial masters will always be 'l/anguish $/[\ldots]$ a foreign anguish' (30) for those who were and are subjected and whose 'native' language was taken away. On the same page, Philip reproduces the language of slave owners to illustrate the process of linguistic expropriation as a strategic means of preventing slave rebellions. While the poem introduces 'father tongue' (30) as the term that more aptly captures the foreignness of English, the 'mother tongue' cannot be fully recuperated-it remains ambivalent, precariously close to 'the overseer's whip'.

A foreignness forcibly imposed on and incorporated by the subject of racial-colonial violence also appears in the respirational intrauterine scene depicted in 'The $\mathrm{Ga}(\mathrm{s}) \mathrm{p}$ ', but in that case it is associated with the child in the mother's womb, the 'occupant' resulting from 'the forced impregnation by white and European masters'. In 'The Ga(s)p' and Philip's literary texts, the roles of mother and child are diametrically opposed. I would like to suggest that, against this background, we can define Philip's poetics of breathing and poetics of the fragment as a poetics of conspiration. If we read the respirational primal scene Philip proposes not only as a 'blueprint for community and interdependency' but also as a blueprint for her poetics of breathing, the 'prepositional relationship with breath' changes ('The Ga(s)p', 31, my emphasis): breathing for turns into breathing with. The intricacies of con-spiration are already negotiated in 'Universal Grammar' with respect to the 'mother tongue' - the language we cannot chose but have. In Zong!, they become the major poetic challenge in the futile attempt of recovering a language lost from the only source we have. As Philip points out in the 'Notanda', 'The text-the reported case-is a matrix - a mother document' (Zong!, 200). 'How do we "breathe with" such a smothering matrix?' 'We blow her to pieces', Philip seems to suggest, describing the composition of Zong! as a textual matricide:

I murder the text, literally cut it into pieces, castrating verbs, suffocating adjectives, murdering nouns, throwing articles, prepositions, conjunctions 
overboard, jettisoning adverbs: I separate subject from verb, verb from object-create semantic mayhem, until my hands are bloodied, from so much killing and cutting. (193)

In contrast to Sara Ahmed's appeal to put up resistance by 'rebuild[ing] the master's residence' after 'shattering' its 'walls', ${ }^{21}$ Philip's poetic engagement with the 'matrix' is neither combative nor restorative. She rather exposes both the violence of the text, and her own violence against it, by leaving it in scattered fragments. Thereby, the notion of residence, which Philip, akin to Ahmed, draws on in her respiratory primal scene ('hospitality', 'housing the stranger'), is abandoned. Here we can pinpoint a crucial difference between the maternal 'breathing for', giving shelter for the occupant in the enclosed space of the womb, and conspiration, 'breathing with' the violent matrix. Conspiring with a 'mother document' articulates itself in dismembered syllabic ga(s)ps that cannot be contained, in parallel with the bodies and voices that cannot be salvaged. Conspiration also implies entering a 'zone of contamination' (Zong!, 199): rather than being undone, the violence of a matrix that is not enclosed unavoidably becomes contagious. As a result, neither the author nor the literary child is any longer innocent: Philip perceives herself as a killer and cutter of the text while the 'castrat[ed] verbs', 'suffocat[ed] adjectives', 'murder[ed] nouns', or 'jettison[ed] adverbs' are imbued with the matrix's oppressive air-maybe this is something the plaintive syllables too bemoan.

Through the idea of isolated syllables, or language cells, Philip's text conspires (perhaps unwittingly) with a literary predecessor through the idea of isolated syllables, or language cells: Charles Olson, whose 1951 essay 'Projective Verse' initiated the American 'poetics of breath' Mackey discusses. The passages in which Olson attends to syllables, 'the elements and minims of language' in 'Projective Verse'22 are reproduced almost word by word from a short piece he wrote in 1946, Mouths Biting Empty Air. In this unpublished essay, syllables and breath are suggestively conjoined; this is not the case in 'Projective Verse', where the discussion of 'particles of sound' (17) does not feature respiratory vocabulary or images. The breath-syllable nexus as it is presented in Mouths Biting Empty Air strongly resonates with Philip's respiratory poetics. The words at the very end of Olson's short essay, 'I give you something with which to breathe, the syllable' (Mouths Biting Empty Air, my emphasis), ${ }^{23}$ intertextually conspire with Philip's claim “"Zong!\#l," $[\ldots]$ is in fact $[\ldots]$ a 
series of ga(s)ps with syllabic sounds attached or overlaid' ('The Ga(s)p', 39). The very different contexts of these sentences as well as of the writers' poetics of breathing in general mean their juxtaposition represents a 'forced coupling' in another sense. A particularly troubling undertone to the echoes between their poetic projects is generated by the fact that Olson's writing has, for good reasons, been criticized for its masculinist stance and colonial insensitivity. ${ }^{24}$ However, it is precisely in these nonharmonious contacts and correspondences that the ambivalences inherent in a poetics of conspiration can be unfolded: For both Philip and Olson, syllables, the elementary particles of language as well as breath, a basic life-sustaining process, are fundamental to poetry. Olson opens 'Projective Verse' with the sentence: 'Verse now, 1950, if it is to go ahead, [...] must, I take it, catch up and put into itself certain laws and possibilities of the breath, of the breathing of the man who writes' (15). The role attributed to the 'particles of sound' in the new poetry is equal to the importance of the 'laws and possibilities of the breath':

Let's start from the smallest particle of all, the syllable. It is the king and pin of versification, what rules and holds together the lines, the larger forms, of a poem.

It would do no harm, as an act of correction to both prose and verse as now written, if both rhyme and meter, $[\ldots]$ both sense and sound, were less in the forefront of the mind than the syllable, if the syllable, that fine creature, were more allowed to lead the harmony on. ('Projective Verse', $17,18)$

Moreover, Philip and Olson associate syllables and breath with 'origin'. Olson hints at a poetic origin when he notes that 'the projective poet will [go], down through the workings of his own throat to that place where breath comes from, [...], where, the coincidence is, all acts spring' (26, my emphasis), and calls syllables 'the minimum and source of speech' (18, my emphasis). The notion of an ontogenic primordiality as it is evoked in Philip's sketch of the intrauterine respirational scene is recalled when she links syllables to an early stage in the process of language acquisition: 'The poems are about language at its most fundamental in the sense of the very basic way in which children put language together when they begin to speak, building syllable on syllable' (195). On a broader, evolutionary, phylogenetic level, she situates the syllabic sounds pervading Zong! in linguistic prehistory: 'Words break into sound, return to their initial and originary 
phonic sound-grunts, plosives, labials—is this, perhaps, how language might have sounded at the beginning of time?' (205).

A phylogenetic notion of origin enters Olson's discussion of the syllables when he illustrates their poetic value-a capacity to enact 'figures' of 'dance' (18)—with etymological speculations that suggest the following Sanskrit roots of English words: ${ }^{25}$

'Is' comes from the Aryan root, as, to breathe. The English 'not' equals the Sanscrit $n a$, which may come from the root $n a$, to be lost, to perish. ' $\mathrm{Be}$ ' is from $b h u$, to grow. (18)

Olson's playful demonstration of how 'the minimum and source of speech' acoustically lead 'the harmony on' (is-as; not-na; be-bbu) goes back to a problematic textual source. The passage is taken from Ernest Fenollosa's controversial essay 'The Chinese Written Character as a Medium for Poetry'. ${ }^{26}$ Praised by Ezra Pound, who published it in his Instigations, the essay was enthusiastically received in the context of avantgarde poetics, while Fenollosa's less than perfect knowledge of Chinese ${ }^{27}$ and, above all, his orientalist and primitivist tendencies were harshly criticized. ${ }^{28}$ Olson's negotiation of the syllable's poetic potential therefore also draws on a mother-text tainted with colonial force. Olson, on the one hand, strongly sympathizes with the essay, calling it the 'damned best piece on language since when'. ${ }^{29}$ On the other, however, both his theoretical and literary-creative treatment of linguistic 'roots', etymons, undermine Fenollosa's discussion of Sanskrit.

The way in which Fenollosa, who considers himself 'an enthusiastic student of beauty in Oriental culture' (359), conceives of the ancient non-Western 'natural' languages goes hand in hand with what Viktor Li conceptualizes as '[a]rcadian primitivism': 'the primitive is seen as a corrective to the malaise of Western Modernity'. ${ }^{30}$ Thereby, 'the more affirmative' primitivism ${ }^{31}$ utilizes a 'rhetoric of contrast' ensuring 'that the alterity or otherness of the primitive is kept in the foreground'; 32 'the primitive is conceived and valued solely as the antithesis of the modern West'. ${ }^{33}$ Fenollosa discusses 'primitive Sanskrit' (377) and Chinese in precisely this manner, as languages closer to nature and 'primitive men' (366) that contrast with the less poetic modern Western languages, which are determined by abstraction and arbitrariness. The passages Olson cites are embedded in this line of argument. Fenollosa attempts to 'reveal' 'ancient roots' of 'our large vocabularies' that 'dealt directly with physical 
processes' (377): almost 'all the Sanskrit roots, which seem to underlie European languages, are primitive verbs, which express characteristic actions of visible nature' (373). This claim is enmeshed in an orientalist narrative of recovery: doing 'consciously what the primitive races did unconsciously', the 'chief work of literary men in dealing with language, and of poets especially lies in feeling back along the ancient lines of advance' (378). When Fenollosa uncovers the 'vivid verbs' (377) of 'primitive Sanskrit', it is no accident that 'breathe' serves as an illustration. By claiming that "Is" comes from the Aryan root, as, to breathe' (36970), he stages a drama of re-animation in which Western 'scholars and poets' 'feel $[\ldots]$ back', reaching right into the womb of the primordial mother-language:

Only scholars and poets feel painfully back along the thread of our etymologies and piece together our diction, as best they may, from forgotten fragments. This anemia of modern speech is only too well encouraged by the feeble cohesive force of our phonetic symbols. There is little or nothing in a phonetic word to exhibit the embryonic stages of its growth. (379, my emphasis)

Olson's pneumatic poetic endeavour is significantly different. The way in which he reflects on etymons and integrates the 'breath-root' in his own writing resists the narrative of retrieving a submerged origin. Even though Olson flirts with the idea of a primal language to which all others can be traced back, ${ }^{34}$ he does not conceive of such an origin as an exotic primordial mother tongue. When he claims that etymological roots, or 'resistant primes' represent an 'impetus and explosion in our alphabetic speech' that puts 'us back to the origins of their force not as history but as living oral law', 35 the origin is uprooted. The 'origin' of the roots' 'force' is not their historical situation in the beginning, but their ability to affect the language spoken and written in the present. What is for Fenollosa the 'feeble cohesive force of our phonetic symbols' is re-evaluated as a 'living oral law' that breaches the boundary between past and present: 'back to the origins' is right now. Olson counteracts a 'rhetoric of contrast' by undermining the orientalist phantasy of a bygone primordial past, a constitutive other on which Western language has to turn back in order to unfold its full poetic potential. For Olson, poetic force is not set free through restauration or reconstruction, but, on the contrary, through 'explosion'. Rather than in 'piecing' the 'forgotten fragments' together 
into a coherent whole, he is interested in setting them loose. In this context, the nexus of syllables and breath as it is presented in Mouths Biting Empty Air is particularly revealing:

'Is' comes from the Aryan root, as, to breathe. The English 'not' equals the Sanscrit $n a$, which may come from the root $n a$, to be lost, to perish. 'Be' is from $b h u$, to grow.

From the root out the syllables come, the figures of the dance. The intricacy lies in the three extending phases from the body $[\ldots]$ to the arms, limbs, leaves, or fingers, and their gestures, out into that third state, movement, where the dance is, and the life proper, where they strike against and pile up one upon the other, or go and stay apart, or fuse and cease to be themselves, any and all the conditions atoms and breath can create by act and multiplication.

Olson explodes rootedness by refusing to identify the source of the etymological speculation and not even marking it as a quotation. Through this act of stealing Fenollosa's words, he gestures towards another etymological implication of breath: in French, souffler is associated with robbing. ${ }^{36}$ Divorced from their context, the words are torn out of the primitivist narrative. Thereby, the colonial burden is not lost, but loosened. It is in this manner that Olson conspires with Fenollosa: rather than revealing how the abstract verb is goes back to breathe, the ultimate embodiment of a 'vivid verb', Olson gives us 'syllables to breathe with'. In his own comment on the passage, he describes a dance of the smallest particles that do not reassemble to a whole. What 'atoms and breath can create' is a partage: the conspiring syllables 'pile up one upon the other, or go and stay apart, or fuse and cease to be themselves'.

Olson's depiction of syllables as 'figures of the dance', bodies in motion, is echoed in Philip's comments on the fragmented language of Zong! when she addresses its resistance against the colonial language of her matrix:

words arrange themselves in odd and bizarre combinations: at times the result appears the verbal equivalent of the African dance style 'crumping,' in which the body is contorted and twisted into intense positions and meanings that often appear beyond human comprehension. At times it feels as if I am getting my revenge on 'this/fuck-mother motherfuckin language' of the colonizer-the way the text forces you-me-to read differently, 
bringing chaos into the language or, perhaps more accurately, revealing the chaos that is already there. (Zong!, 205)

According to Philip, the resistant chaos of verbal crumping is unleashed when words are dissected into syllables. It is precisely in this context that she alludes to language in a primordial state:

the ordering of grammar, the ordering that is the impulse of empire is subverted [...;] words are broken into and open to make non-sense or no sense at all $[\ldots$ and $]$ return to their initial and originary phonic sound. (205)

In line with Olson's claim that '[ $t]$ his place of the elements and minims of language, is to engage speech where it is least careless-and least logical' ('Projective Verse', 18), Philip adds the argument that the non-sense of acoustic particles, 'phonic sound-grunts, plosives, labials', disrupts the sense and logic of the colonizer's discourse. As Fenollosa's essay shows, one trait of the 'language of the colonizer', if he is engaging in an '[a]rcadian primitivism', is to condemn the rationalism of Western languages and juxtapose it with a romanticized non-logical primitive language: all 'nations have written their strongest and most vivid literature before they invented grammar'. '[M]odern speech' suffers 'anemia' because '[a]bstract meaning gives little vividness' (376) and 'the ordinary western mind' is only 'concerned with logical categories' (376).

How does Philip's invocation of a chaotic, non-sensical language 'at the beginning of time' relate to this? The syllabic gasps she stages in Zong! are also deemed poetic, but in an utterly non-idyllic manner. In contrast to the 'vivid' impulses of primordial speech as Fenollosa theorizes it, Philip's 'language of grunt and groan, of moan and stutter-this language of pure sound fragmented' (Zong!, 205) is imbued with death and suffering. This also marks a significant difference to Olson's discussion of syllables, which, in his view, embody a 'life proper', 'lead the harmony on', and make words 'juxtapose in beauty' ('Projective Verse', 17). For Philip, the primordial asemantic sounds do not characterize a particular language; they rather mark a moment when to 'loose a language' coincides with to 'lose a language': 'The loss of language and meaning on board the Zong levels everyone to a place where there is, at times, no distinction between languages - everyone, European and African alike, has reverted, it appears, to a state of pre-literacy' (Zong!, 206). This state exposes a multilingual 'cacophony of voices-wails, cries, moans, and shouts' (203); sometimes, what might look like asemantic fragments do make sense, in 


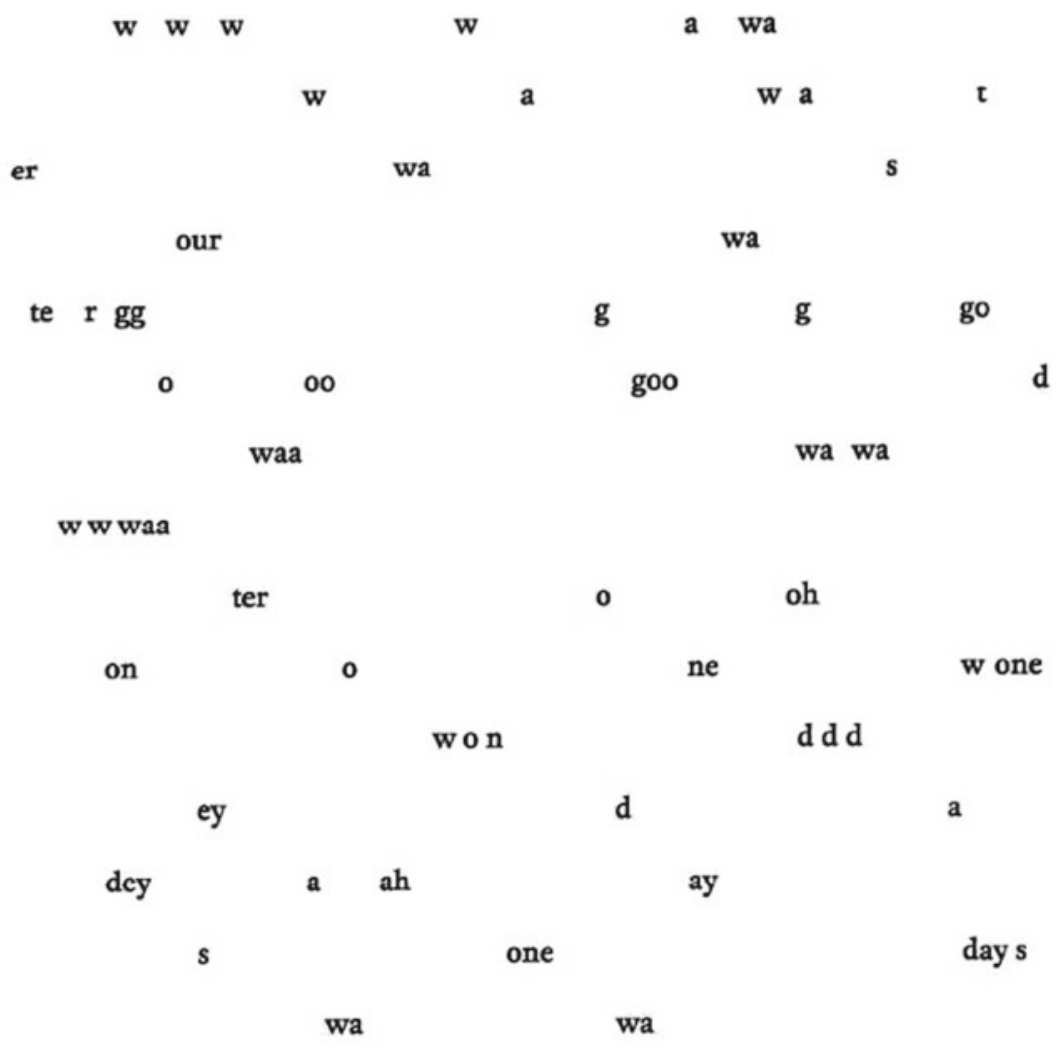

Fig. 22.1 Zong!\#I

languages other than English: 'os: bone' (Latin) (183), 'wa àgbò: look for the ram', 'ní mi ni ran: remind me' (Yoruba) (184), etc. In Zong!, the language Philip associates with 'the beginning of time' thwarts the orientalist idea of a primordial Eastern/African mother tongue. By presenting dispersed languages on the verge of non-language, Zong! shatters the singular mother tongue, be it Western or non-Western, along with the matrix. By starting to conspire in this manner, languages are uprooted (Fig. 22.1).

Zong!\#1, which, according to Philip 'is in fact an extended ga(s)p, or rather a series of ga(s)ps for air with syllabic sounds attached or overlaid', thwarts a narrative of recovery in yet another manner. It reveals that the gasp is always already a gap. In line with Philip's claim that 'the poems-need a great deal of space around them-as if [...] they need to 
breathe' (194), Zong!\#I marks 'breathing space' (195) by white space. This seems to exemplify how 'breathing and the breath were built into the text of Zong!' ('The Ga(s)p', 38). However, the white space Philip identifies with breathing space displays an absence of respiration, pointing to the impossibility of incorporating breathing into the book. Zong! thus stages breath-less conspiration: a 'breathing with' that turns out to lack-be without-physiological breath. When Philip wonders 'whether the sounds of those murdered Africans continue to resound and echo underwater' because she heard that 'sound never ceas[es] within water' (Zong!, 203), she seems to imply that transferred to moans, bones might after all be recoverable 'exaqua': in syllabic gasps as they are presented in Zong!\#l, for example, where the word 'water' itself is cut into wailing sounds. A closer look at the scattered 'syllables' Philip gives us 'to breathe with' shows that instead of the magical transformation of bones into moans we encounter the transmission of ga(s)ps. Just as Philip cannot recover the bones, her text cannot 'breathe for' the killed slaves. The conspiration performed is a partage: sharing a lack. If this conspiration functions as a 'blueprint for community and interdependency', 'acceptance of alterity' implies an acceptance of the irredeemable. Zong! reverses the 'metamorphosis from sound to intelligible word' based on violent premises Philip addresses in She Tries Her Tongue. However, blowing the violent matrix of the legal text and the colonial mother tongues to pieces, the poems do not constitute a receptacle for recovered breath. The title of the book's first section, 'os', seems to encompass the transformation from bones to moans in a most condensed manner: in Latin, the word means both bone and mouth, the place from which breath and sounds are emitted; acoustically, 'os' could be an ululation issued from an open mouth visually evoked by the letter ' $\mathrm{O}$ '. At the same time, 'o' figures a gaping void: what reminds us of a mouth enclosing sounds is also a mute letter that fails to contain breath and sound. It seems no coincidence that in Zong!\#l, 'o' and 's' never fuse into the noun that-in a Western language of colonizers, and the language of the law par excellence-sparks a hope of retrieval: 'os', the potential bones-moans-metamorphosis. They do so in Zong!\#2 (5), embedded in the following words, surrounded by white space:

the loss 


\section{Notes}

1. M. NourbeSe Philip, 'The Ga(s)p', in Poetics and Precarity, ed. by Myung Mi Kim and Cristanne Miller (Albany: State University of New York Press, 2018), 31-40, 39. All subsequences references to 'The Ga(s)p' are to this edition, cited by page number.

2. Nathaniel Mackey, 'Breath and Precarity', The Inaugural Robert Creeley Lecture in Poetry and Poetics, in Poetics and Precarity, 1-30, 5. All subsequences references to Mackey are to this edition, cited by page number.

3. The only woman musician he discusses is fictional: the drummer Drennette, a character of Mackey's From a Broken Bottle Traces of Perfume Still Emanate (cf. Mackey 10-13).

4. Otto Rank, The Trauma of Birth (London: Kegan Paul, 1929), 11.

5. Rank, The Trauma of Birth, 8.

6. Rank, The Trauma of Birth, 17.

7. Maurice Merleau-Ponty, 'The Child's Relation with Others', in The Merleau-Ponty Reader, ed. by Ted Toadvine and Leonard Lawlor (Evanston: Northwestern University Press, 2007), 143-183, at 151.

8. David Michael Kleinberg-Levin, Before the Voice of Reason. Echoes of Responsibility in Merleau-Ponty's Ecology and Levinas's Ethics (Albany: State University of New York Press, 2008), 79.

9. Peter Sloterdijk, Bubbles. Spheres I, trans. by Wieland Hoban (Pasadena, CA: Semiotext(e), 2011), 297-98. Leo Bersani, Receptive Bodies (Chicago: University of Chicago Press, 2018), 86.

10. Bersani, Receptive Bodies, viii.

11. Bersani, Receptive Bodies, 85.

12. Jean-Luc Nancy, The Inoperative Community, trans. and ed. by Peter Connor (Minneapolis: University of Minnesota Press, 1991), xxxviii.

13. Jean-Luc Nancy, The Disavowed Community, trans. by Philip Armstrong (New York: Fordham University Press, 2016), 1, 9.

14. Nancy, The Inoperative Community, 33.

15. Nancy, The Inoperative Community, xxxix.

16. M. NourbeSe Philip, Zong! (Middletown, CT: Wesleyan University Press, 2011). All subsequences references to Zong! are to this edition, cited by page number.

17. M. NourbeSe Philip, 'Defending the Dead, Confronting the Archive: A Conversation with M. NourbeSe Philip', Small Axe 26 (2008), 63-79, at 73.

18. Christina Sharpe, In the Wake. On Blackness and Being (Durham, NC: Duke University Press, 2016), 109.

19. Cf. Sharpe, In the Wake, 38, and Sarah Dowling, 'Persons and Voices: Sounding Impossible Bodies in M. NourbeSe Philip's Zong!', Canadian Literature/Littérature Canadienne 210/211 (2011), 43-58, at 45-46. 
20. M. NourbeSe Philip, She Tries Her Tongue, Her Silence Softly Breaks (London: The Women's Press, 1993), 37. All subsequences references to She Tries Her Tongue are to this edition, cited by page number.

21. Sara Ahmed, Living a Feminist Life (Durham, NC: Duke University Press, 2017), 7, 175.

22. Charles Olson, 'Projective Verse', in Selected Writings, ed. by Robert Creeley (New York: New Directions, 1966), 15-26, at 18. All subsequences references to 'Projective Verse' are to this edition, cited by page number. For a detailed analysis of Olson's treatment of breath in 'Projective Verse' and beyond see Stefanie Heine, Poetics of Breathing. Modern Literature's Syncope (Albany, NY: State University of New York Press, 2021), 108-115.

23. Charles Olson, Mouths Biting Empty Air (1946), typescript, I Box 32:1630, prose no. 15, Charles Olson Research Collection, University of Connecticut. The essay, held at the Thomas J. Dodd Research Center in Connecticut, is not paginated.

24. For Olson's celebration of masculinity see Rachel Blau DuPlessis, 'Olson and His Maximus Poems', in Contemporary Olson, ed. by David Herd (Manchester: Manchester University Press, 2015), 135-48. For a discussion of his problematic treatment of Mayan glyphs see Andrew Mossin, "'In Thicket": Charles Olson, Frances Boldereff, Robert Creeley and the Crisis of Masculinity at Mid-Century', in Olson's Prose, ed. by Gary GrieveCarlson (Newcastle: Cambridge Scholars Publishing, 2007), 16-46; Joel Duncan, 'Frank O'Hara Drives Charles Olson's Car', Arizona Quarterly: A Journal of American Literature, Culture, and Theory 72/4 (2016), 77103; Daniel Katz, 'From Olson's Breath to Spicer's Gait: Spacing, Placing, Phonemes', in Contemporary Olson, 78-88.

25. These etymologies are oversimplified and partly incorrect. For a discussion of this matter with regard to Olson's poetics see Stefanie Heine, 'Fishy Etymologies', Sprachgeschichtliche Irrwege bei Charles Olson, Colloquium Helveticum 46 (2017), 131-43.

26. Ernest Fenollosa, 'The Chinese Written Character as a Medium for Poetry', in Instigations, ed. by Ezra Pound (New York: Boni and Liveright, 1920), 357-88. All subsequences references to 'The Chinese Written Character' are to this edition, cited by page number. In Fenollosa's text, the sentences do not occur directly after each other. Olson deliberately arranges them in a way that highlights a rhythmic quality and tonal continuity.

27. E.g., George A. Kennedy, 'Fenollosa, Pound and the Chinese Character', Yale Literary Magazine 126/5 (1958): 24-36.

28. For a discussion of these tendencies, see Robert Kern, Orientalism, Modernism, and the American Poem (Cambridge: Cambridge University 
Press, 1996), 115-45. For a very nuanced overview of Fenollosa's ambivalent reception, see Haun Saussy's introduction to Ernest Fenollosa and Ezra Pound in The Chinese Written Character as a Medium for Poetry: A Critical Edition, ed. by Haun Saussy, Jonathan Stalling, and Lucas Klein (New York: Fordham University Press, 2008).

29. Charles Olson, 'The Gate and the Center', in Collected Prose, ed. by Donald Allen and Benjamin Friedlander (Berkeley: University of California Press, 1997), 168-73, at 168.

30. Victor Li, 'Primitivism and Postcolonial Literature', in The Cambridge History of Postcolonial Literature, ed. by Ato Quayson (Cambridge: Cambridge University Press, 2012), 982-1005, at 986, https://doi.org/ $10.1017 /$ chol9781107007031.011.

31. Li, 'Primitivism and Postcolonial Literature', 985.

32. Li, 'Primitivism and Postcolonial Literature', 984.

33. Li, 'Primitivism and Postcolonial Literature', 987.

34. Cf. 'The Gate and the Center', 168.

35. 'The Gate and the Center', 168.

36. Jacques Derrida, 'La parole soufflée', in Writing and Difference, trans. by Alan Bass (London: Routledge, 2001), 213-45, at 222.

\section{Selected Bibliography}

Ahmed, Sara. 2017. Living a Feminist Life. Durham, NC: Duke University Press. Bersani, Leo. 2018. Receptive Bodies. Chicago: University of Chicago Press.

Derrida, Jacques. 2001. La parole soufflée. In Writing and Difference, trans. by Alan Bass, 213-45. London: Routledge.

Dowling, Sarah. 2011. Persons and Voices: Sounding Impossible Bodies in M. NourbeSe Philip's Zong!. Canadian Literature/Littérature Canadienne 210/211: 43-58.

Kim, Myung Mi, and Cristanne Miller, eds 2018. Breath and Precarity. The University at Buffalo Robert Creeley Lectures in Poetry and Poetics. Albany: State University of New York Press.

Li, Victor. 2012. Primitivism and Postcolonial Literature. In The Cambridge History of Postcolonial Literature, ed. by Ato Quayson, 982-1005. Cambridge: Cambridge University Press. https://doi.org/10.1017/chol97811070070 31.011 .

Merleau-Ponty, Maurice. 2007. The Child's Relation with Others. In The Merleau-Ponty Reader, ed. by Ted Toadvine and Leonard Lawlor, 143-83. Evanston: Northwestern University Press.

Nancy, Jean-Luc. 1991. The Inoperative Community. Trans. and ed. by Peter Connor. Minneapolis: University of Minnesota Press. 
Nancy, Jean-Luc. 2016. The Disavowed Community. Trans. by Philip Armstrong. New York: Fordham University Press.

Sharpe, Christina. 2016. In the Wake: On Blackness and Being. Durham, NC: Duke University Press.

Open Access This chapter is licensed under the terms of the Creative Commons Attribution 4.0 International License (http://creativecommons.org/licenses/ by $/ 4.0 /)$, which permits use, sharing, adaptation, distribution and reproduction in any medium or format, as long as you give appropriate credit to the original author(s) and the source, provide a link to the Creative Commons license and indicate if changes were made.

The images or other third party material in this chapter are included in the chapter's Creative Commons license, unless indicated otherwise in a credit line to the material. If material is not included in the chapter's Creative Commons license and your intended use is not permitted by statutory regulation or exceeds the permitted use, you will need to obtain permission directly from the copyright holder.

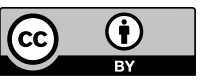

